\title{
GRADEC IN SLOVENCI
}

STANE GRANDA

Gradec je bil vse do prve svetovne vojne upravno, kulturno, gospodarsko in politično središč Štajerskega, v katerem so Slovenci predstavljali tretjino prebivalstva. Tako kot Trst na zahodu slovenskega etničnega ozemlja je bil vabljivo mesto za družbeni vzpon in kariere številnih Slovencev. Do 1919, tj. do ustanovitve univerze v Ljubljani, je bila graška univerza ob Dunaju in manj Zagrebu tudi glavno univerzitetno središč Slovencev. Gradec je bil mesto, v katerem so se porajale in uresničevale številne nove zamisli.

Ključne besede: Gradec, univerza, Slovenci
Until the First World War, Graz was the administrative, cultural, economic, and political center of Styria, in which Slovenians represented one third of the population. Thus, like Trieste on the west of Slovenian ethnic territory, the city attracted many Slovenians interested in advancing themselves socially and building careers. Until the founding of the University of Ljubljana in 1919, alongside the universities in Vienna and (to a lesser extent) Zagreb, the University of Graz was also a major university center for Slovenians. Graz was a city in which many new ideas were engendered and came to fruition.

Keywords: Graz, university, Slovenians

Nenavadno je dejstvo, da sta na robu slovenskega etničnega ozemlja kar dve mesti, ki ne bosta nikoli mogli skriti slovenskega izvora svojega imena; to sta Gorica in Gradec.

O tem, da je bil Gradec, katerega ime je nedvomno slovensko, kratek čas slovenski, najzgovorneje pove dejstvo, da so morali pri Slovenj Gradcu že 1165. leta poudarjati njegovo slovenstvo, ${ }^{1}$ medtem, ko se je za pozneje glavno mesto Štajerske uporabljalo ime bavarski gradec. Pomen Gradca je za Slovence naraščal skladno z oblikovanjem dežele Štajerske, katere izhodišče je bila Karantanska krajina. Ta se je leta 1035 dokončno ločila od koroške vojvodine. Za njeno oblikovanje imajo veliko zaslugo Traungavci, ki so se jim 1156. leta podvrgli svobodni gospodje iz Stübinga, lastniki Gradca, ki je začel postajati središče nove dežele. Otokar IV. Traungavski je bil 1180. leta povzdignjen v štajerskega vojvodo in je načeloval vojvodini Štajerski. Med letoma 1192 in 1246 so bili na čelu Štajerske Babenberžani, od 1282. leta pa po vmesnih zapletih s češkim kraljem Otokarjem II. Přemyslom in ogrskim kraljem Belo IV. Habsburžani. 1311. leta so ti priključili tudi Posavinje. Medtem ko se je vzhodna meja oblikovala že poprej, se je tedaj ustalila tudi današnja južnoštajerska meja na Savi. Dejansko pa je dežela Štajerska dokončno zaživela kot celota po izumrtju grofov Celjskih, ki so do 1456. leta še bili ovira temu procesu.

Štajerska je tako postala dežela, kjer je bil njen južni, slovenski del zaradi pridelave

1 Windisken Graze. Historična topografija Slovenije II, Pavle Blaznik, Slovenska Štajerska in jugoslovanski del Koroške do leta 1500. 2, N-Z̈. Maribor, 1988: 299. 
hrane in vina izjemno pomemben za gospodarstvo dežele, katere sever je bil bolj metalurški. Poleg tega, da je Gradec postal glavno mesto dežele, kjer so Slovenci predstavljali vsaj tretjino prebivalstva, pa je bila dežela kot taka vzorec za pravno oblikovanje drugih dežel s slovenskim prebivalstvom (od deželnega ročina, gorskih bukev in nekaterih drugih temeljnih dokumentov). V tem pogledu je njen pomen za slovensko zgodovino premalo cenjen, kar pa ni nenavadno, če upoštevamo dejstvo, da slovensko zgodovinopisje srednjega veka, z izjemo novejšega (Peter Štih in njegova »šola«), premalo upošteva pravne vidike.

Poleg tega, da je bil Gradec kot sedež dežele pomemben za štajerske Slovence, pa je bil z oblikovanjem notranjeavstrijskih dežel (proces se je začel že leta 1379) pomemben za vse habsburške Slovence. Notranja Avstrija je bila v letih 1564-1619 praktično samostojna država in je razen ogrskih in beneških povezovala vse Slovence. Neformalno je obstajala vse do reform Marije Terezije sredi 18. stoletja. Pomen Gradca kot glavnega mesta te naddeželne enote je bil izjemen. V njem so bili pomembni državni organi, primerljivi le z dunajskimi. Notranja Avstrija je bila organizator skupne naddeželne obrambe proti Turkom, skrbela je ne le za njen vojaško-operativni del, temveč tudi finančni, kar je prispevalo k velikemu razcvetu mesta. Upravljanje s financami je bilo v zgodovini vselej med najdonosnejšimi viri individualnega in tudi skupnega bogatenja.

Pomena Notranje Avstrije in Gradca kot glavnega mesta ne gre poudarjati le, ko razpravljamo o protiturški obrambi, temveč tudi ko mislimo na kulturnoprosvetno problematiko. $\mathrm{V}$ čas nekakšne državnopravne samostojnosti te naddeželne notranjeavstrijske enote sodi nastanek univerze 1586. leta. Kakor vemo, ljubljanska ni zaživela, čeprav je imela pravzaprav enak privilegij. $V$ ta čas sodi vodenje in usmerjanje protireformacije; Gradec je postal kulturno središče vseh Slovencev - tu je bila leta 1574 izdana prva katoliška slovenska knjiga. Poseben pomen Štajerske je viden še tudi pozneje, zlasti v 19. stoletju, in še posebej v času nadvojvode Janeza, ki ni omogočil le začetek izdajanja Novic, temveč je tudi drugače blagodejno vplival na razvoj slovenskega slovstva.

Notranja Avstrija je bila pomembna tudi za oblikovanje slovenskega političnega samouresničevanja. Kadar so Slovenci obupovali nad zamislijo o združeni Sloveniji in se niso navduševali v smeri ilirizma ali jugoslovanske ideje, so se vedno zatekli k ideji o ponovni oživitvi Notranje Avstrije kot nekakšnem nadomestku zanjo. V njej bi bili namreč Slovenci v primerjavi z Nemci večina in bi po demokratični poti lažje uresničili svoje temeljne narodne cilje glede jezikovnih pravic.

Zanimiv je tudi nastanek Gradca kor verskega središča. Kakor je poznano, je na začetku 9. stoletja postala Drava meja med Oglejem in salzburško škofijo. Ta je na svojem ozemlju razvila nekaj sebi podrejenih škofij, med katerimi je bila 1218. leta ustanovljena škofija v Seckauu (v 19. stoletju so Slovenci, ki so bili tudi med oskrbniki posestva, uporabljali ime Sekova) blizu Lipnice. Čeprav so njeni škofje običajno bivali v Gradcu, pa je ta postal njen sedež šele ob koncu 18. stoletja, že potem, ko so prišli pod njeno jurisdikcijo ozemlje do Drave oziroma graška in mariborska kresija. Vanjo je prišlo okoli 200 tisoč štajerskih 
Slovencev, zlasti tistih iz Slovenskih goric, z izjemnim intelektualnim in nacionalnim potencialom. Čeprav so bili med njimi številni izvrstni duhovniki, jih težko najdemo med člani graškega stolnega kapitlja. Očitno je bil njihov socialni položaj prenizek za takšne, finančno donosne službe. Mogoče je pozneje, zlasti v 19. stoletju, na tak odnos do duhovnikov Slovencev vplivalo dejstvo, da je bilo med njimi veliko resničnih narodnjakov. Problem je razrešil šele Slomšek 1859. leta.

Elementi Gradca kot pomembnega središča vseh Slovencev - in štajerskih še posebej - so torej upravnopolitični, prosvetni in kulturni, znanstveni in verski.

Upravnopolitična vloga Gradca je bila deželna in naddeželna. Tu je bila vrsta upravnosodnih in finančnih organov razvijajoče se deželne in državne uprave, ki je zaposlovala tudi številne ljudi slovenskega rodu. Tu so se sestajali štajerski deželni stanovi, glavni nosilci štajerske deželne zavesti, ki se je izredno razširila tudi po slovenskem etničnem ozemlju in se oplajala tudi na meddeželnem antagonizmu. Štajerski Slovenci zato Gradca niso občutili kot tujega, nemškega, ampak kot svoje štajersko glavno mesto, ki je postalo življenjski cilj mnogih ambicioznih, tudi slovenskih, deželanov. Popis hišnih lastnikov iz srede prve polovice 19. stoletja kaže, po priimkih, izjemno visok odstotek slovenskih lastnikov. Ker pa so priimki pri štajerskih Slovencih zelo nezanesljiv podatek za določanje nacionalnega izvira, je bilo med njimi Slovencev gotovo še veliko več. Tak položaj Gradca v zavesti štajerskih Slovencev se je pokazal tudi v tem, da so spodnještajerska mesta in trgi darovali, zlasti v 19. stoletju, v tamkajšnje arhivske ustanove, zlasti v Joanneum, dragocene arhive, ki so še danes tam. In nikakršne pravne podlage ni, da bi jih lahko terjali nazaj. Prav tako je slovensko dojemanje glavnega deželnega mesta ob koncu 19., zlasti pa v 20. stoletju, motilo nemške nacionaliste, zato je bil protislovenski boj še posebno izrazit. To je imelo posledice tudi za razmah nacizma in poznane priprave na zasedbo Slovenije in Jugoslavije. V Gradcu so bili sestavljeni seznami za izseljevanje Slovencev med drugo svetovno vojno. Danes je mesto kozmopolitsko, strpno in Slovencem dokaj naklonjeno.

Izjemen kulturno-prosvetni pomen za Slovence je Gradcu dala protireformacija. Najprej je treba omeniti univerzo, ustanovljeno 1586. leta. Jožef II. jo je leta 1782 sicer znižal na raven liceja, univerza je znova postala šele 1827 . leta. ${ }^{2}$ Pomen univerze ni samo v univerzi kot taki, ampak zlasti v njeni bližini slovenskemu etničnemu ozemlju. Tako je še posebno pritegnila slovenske Štajerce, saj so imeli v mestu številne sorodnike, pri katerih so lahko stanovali. Ne da bi se podrobneje posvečali sicer dokaj dobro raziskanim tamkajšnjim študentskim združenjem, lahko zapišemo, da so postala kovačnica slovenstva. Kakor je bila beseda Slovenec na Štajerskem veliko bolj živa kakor na Kranjskem, tako so bili tudi slovenski študentje v Gradcu veliko zavednejši Slovenci kot nekateri drugi. ${ }^{3}$ To je posebno prišlo do izraza v revolucionarnem letu 1848, ko so organizirali posebno študentsko slo-

2 Nastanek prve katedre za slovenski jezik in graško slavistiko puščamo ob strani, ker je obravnavana v drugih prispevkih.

3 Fran Petre, Poizkus ilirizma pri Slovencih. Ljubljana, 1939. 
vensko/slovansko legijo in tako zanetili narodni spor, ki ni odmeval le v takratnem graškem časopisju, temveč je moralo posredovati celo vodstvo univerze. Dejansko so graški študentje $\mathrm{v}$ sodelovanju z duhovniki postavili strukture narodne organizacije, ki v drugih slovenskih deželah nima primerjave. Ne gre toliko za številčnost, ampak zlasti za operativnost. Gradec je bil v letu 1848 eno avtonomnih idejnih središč v formuliranju slovenskega narodnega programa. Zanimivo je dejstvo, da srečamo v Gradcu leta 1848 tudi Jožefino Oblak, prvo politično dejavno Slovenko, ki ni le darovala slovenskim študentom slovenske zastave, takšna je visela tudi na njeni hiši, ampak je tudi podpisala peticijo za Združeno Slovenijo. ${ }^{4}$

Tudi v naslednjih letih so graški slovenski študentje odigrali pomembno vlogo v narodnem in političnem razvoju Slovencev. Pri tem so bila pomembna tudi društva, ki so bila prvenstveno literarna.

V zvezi z protireformacijo moramo omeniti tudi pomen graškega tiskarstva. - V Gradcu je 1592. leta Megiser izdal svoj štirijezični slovar, tu je izšla še vrsta del, ki veljajo za temeljna v zgodovini starejše slovenske literature. Kot eno velikih avstrijskih mest je Gradec žarčil na slovensko podeželje tudi sodobne filozofske, estetske in politične nazore, ki so jih bili deležni štajerski Slovenci. In tako ni naključje, da so bili v številnih pogledih pred drugimi, pa naj gre za sodobno časopisje, čitalnice, tabore, delniške družbe in podobno. Naposled je večjo odprtost slovenske Štajerske novim pogledom na vseh področjih, zlasti pa pri modernizaciji gospodarstva in družbe, pripisati tudi vlogi in pomenu glavnega deželnega mesta.

V zvezi z verskim pomenom Gradca bi opozorili zlasti še na pomen in vlogo graškega semenišča, kjer so se izobraževali mladi slovenski duhovniki. Vejetno je prav njihovo sobivanje z nemškimi ostrilo in krepilo močno in dokaj nepopustljivo narodno zavest. Posebej je to očitno, če jih primerjamo npr. s koroškimi bogoslovci, ki so, razen v času, ko jih je poučeval in vodil Slomšek, v tem pogledu precej zaostajali. Pri graških bogoslovcih preseneča zlasti pogum pri izražanju slovenske narodne zavesti.

Poznano je, da štajerski Slovenci s svojimi graškimi škofi niso imeli ravno sreče. Če jim je bil v času intenzivnega narodnega prebujanja ob koncu prve polovice 19. stoletja Roman Sebastijan Zängerle vsaj nekoliko naklonjen, pa jim je bil njegov naslednik in poznejši dunajski kardinal Rauscher prav nasproten in jim ni pripisoval prihodnosti. Zanimivo je dejstvo, da so si prav sekavski duhovniki prizadevali za ločitev od graške škofije in združitev z lavantinsko, ki je postala potem škofija za slovenske Štajerce. Graška škofija je pri oblikovanju meje s Slomškovo lavantinsko obdržala okoli 20 tisoč Slovencev, za katere pa ni imela razumevanja. Vsekakor je težko primerjati Gradec kot sedež škofije s pomenom Gradca kot upravnega, kulturnega in siceršnjega intelektualnega središča štajerskih Slovencev.

Prek Gradca se Slovenci niso seznanjali samo z reformacijo, temveč tudi z nekaterimi drugimi verskimi gibanji, npr. z nemško svobodno katoliško cerkvijo in podobno. Iz Gradca se je ob koncu 19. stoletja širilo na slovensko ozemlje, zlasti v Maribor, tudi znano gibanje Loß vom Rom.

4 Stane Granda, Graška Slovenija v letu 1848/1849. Zgodovinski časopis 28, 1974: 45-84. 
Kljub izjemnemu pomenu za štajerske Slovence kot tudi Slovence nasploh, saj je bil Gradec neposredno pravzaprav pomembnejši od Dunaja, pa ni nikoli zasenčil pomena cesarske prestolnice. Paternalističnim predstavam Slovencev je Dunaj kot cesarsko mesto, kot prebivališče vladarja, vselej pomenil neprimerno več. Večina sodobnikov pa vidi v glavnem mestu Štajerske le še tuje mesto. O tem pričajo tudi zapleti z (Janezom) Johannom Pu(c)hom, ki ga vrsta slovenskih zgodovinarjev ni pripravljena sprejeti za Slovenca, ker je kot iznajditelj in podjetnik živel in deloval v Gradcu.

Ne glede na takšne spreglede ostaja pomen Gradca za Slovence še vedno zelo velik. Na njeni univerzi še danes študirajo številni slovenski Štajerci. Izjemen pomen ima tudi tamkajšnji inštitut za džez, kjer so Slovenci tudi med uglednimi profesorji. Mogli bi omeniti še števile druge ustanove, od kulturnih (Opera!) do bolnišnice. Ob krizi mariborskega gospodarstva so v Gradcu našli zaposlitev številni, ki so pri nas formalno brezposelni. $V$ perspektivi lahko postane Gradec tudi pomembno tržišče za slovenještajersko kmetijstvo.

Za slovensko humanistiko pa bo Gradec trajno pomemben ne le zaradi univerze, temveč zlasti Joanneuma in bogatih arhivov, ki so dobro urejeni in dostopni. Izjema je gradivo iz obdobja nacizma, ki je (po mojih informacijah) še vedno nekje skrito. Pred osamosvojitvijo je obstajal celo načrt, da bi v Gradcu načrtno zbirali slovensko emigrantsko literaturo, ki pri nas ni bila splošno dostopna. Zamisel ni bila uresničena, pa tudi danes bi bila brez pravega smisla.

Če je bil za Slovence Gradec stoletja pomembnejši od Ljubljane, je nastanek prve Jugoslavije to bistveno spremenil. Slovenskoštajerska navezanost nanj je začela upadati. Kljub temu tega procesa ne gre preveč poudarjati, ker ne moremo trditi, da je povsem usahnil. Med drugo svetovno vojno je pomen Gradca za slovenske Štajerce spet narasel, po njej je bil razmeroma zaželen cilj za številne politične begunce. Ko se je v 60. letih 20. stoletja sprostil promet prek avstrijsko-jugoslovanske meje, pa je postal znova pomemben za iskanje boljšega zaslužka, kot nakupovalno središče in, navsezadnje, tudi za shranjevanje deviznih prihrankov v tamkajšnjih bankah. Še nedavno je bilo v njem mogoče srečati številne Slovence, nekdanje delavce »na začasnem delu v tujini«, ki so jim v Gradec nakazovali pokojnine, saj so jih doma dobili v nekonvertibilni valuti. S slovensko osamosvojitvijo je njegov mednarodni pravni status neprimerljiv z Ljubljano, kar pa nikakor ne zmanjšuje njegovega realnega, vsakdanjega pomena za številne Slovence, ne le štajerske. Med drugim imajo imajo nekatere slovenske univerze s tamkajšnjimi štirimi razmeroma dobre stike. Zlasti na področju kulture je Gradec Slovencem lahko mnogokrat vzor.

Izr. prof. dr. Stane Granda

Zgodovinski inštitut Milka Kosa ZRC SAZU

Novi trg 2, 1000 Ljubljana

Stane.Granda@zrc-sazu.si 